\title{
Sensory Style Preference of EFL Students in Iran
}

\author{
Mansoor Fahim \\ Islamic Azad University of Science and Research Branch, Iran \\ Email:dr.mfahim@yahoo.com \\ Tania Samadian \\ Islamic Azad University of Science and Research Branch, Iran \\ Email: tnsamadian@yahoo.com
}

\begin{abstract}
This study aimed at finding a relationship between the sensory style preference of learners and their years of experience as EFL (English Foreign Language) student sat secondary school level in Iran. Two questionnaires were used in this study. The first a demographic questionnaire, the latter which was taken from O'Brian (1990) was the Learning Channel Preference Checklist. The participants of this study consisted of 60 girl junior high school students studying at a state school in the city of Mashhad. The participants were divided into two groups: experienced group and inexperienced group. To answer the question of this study, several descriptive and inferential data analyses were utilized. The implication of this study was that there was in fact a significant relationship between the sensory style preference of learners' and that the experienced learners showed a flexibility towards the different learning styles whereas the inexperienced showed no flexibility.
\end{abstract}

Index Terms — sensory style preference, cultural difference, individual learning needs

\section{INTRODUCTION}

It seems that a lot of attention has been given in recent years to students' learning styles in education in general and in FLL (Foreign Language Learning) in particular. To Anderson (2005) an important feature in L2 research is the relationship between language learning strategies and learning styles. These two elements are not in isolation of one another, rather they are intertwined. Cohen \& Macaro (2007) suggest that in an ideal world teachers should be aware of learners' styles and wide variety of strategies that are used for these styles. In this way teachers could accommodate learners to help them progress as quickly as possible in their task of learning a language. Teachers should therefore teach learners how to self-assess their learning styles and strategy usage and to then help them monitor theses issues themselves. Researchers can play a significant role in exploring explicit links between learners' use of strategies, their preferred learning style and language learning.

Unfortunately Iranian English language learners struggle a lot with their English classes at all levels. They normally find their classes not so easy, mundane and useless. However, they try very hard to do well in the final exams which they are pressured to perform well on, as a lot is at stake for them partly because of an extremely competitive university entrance exam. In order to do well in such exams they even go to great lengths to memorize a fair amount of their textbooks .This act is possibly due to the wrong approach to learning English, i.e. the Grammar Translation. Celci-Murcia (2001, p.6)) lists the characteristics of the GTM (Grammar Translation Method) as follows:

$\sqrt{ }$ Instruction is given in the native language of the students.

$\sqrt{ }$ There is little use of the target language for communication.

$\sqrt{ }$ Focus is on grammatical parsing, i.e. the form and inflection of words.

$\sqrt{ }$ There is early reading of difficult texts.

$\sqrt{ }$ A typical exercise is to translate sentences from the target language into the mother tongue (or vice versa)

$\sqrt{ }$ The result of this approach is usually an inability on the part of the student to use the language for communication.

$\sqrt{ }$ The teacher does not have to be able to speak the target language.

The entire list above is unfortunately pronounced in Iranian English classes. However, institutes in Iran have adapted the more productive communicative approach, along with task-based, notional -functional syllabuses. The problem of State program regarding English Classes seems to lie on the consequences of adopting GTM approach.

According to Richards \& Rodgers (2001) although the Grammar-Translation method creates frustrations for students, more often than not, it makes few demands on the teachers. They continue that, though it may be true to say that the Grammar-translation Method is still broadly executed, it has no advocates. There is no literature that offers a rationale or justification for it or that attempts to relate it to issues in linguistics, psychology, or educational theory. The question is: then why is it so extensively used in Iran?

Taking a new approach to teaching English at state schools of Iran, could alleviate the problems and frustrations of students. For this to happen, many researches have to be conducted. Problems have to be scrutinized from different angles and analyzed. For starters, looking at students as active participants rather than passive consumers seems to be 
helpful. Students are unique and have individual learning needs, for one they have different learning styles. According to Richards \&Schmidt (2002), differences in cognitive style are thought to affect how learners approach learning tasks and may affect success on those tasks. Catering for their different needs and giving value to learners as fundamental part of the learning system is paramount.

Harmer (2001) asserts that a preoccupation with learner personalities and styles has been a major factor in psycholinguistic research. The important questions to be dealt with in this field are as follows: Are there different kinds of learner? Are there different kinds of behavior in a group? How can we tailor our teaching to match the personalities in front of us?

Learning Style

It seems that scholars look at learning styles from different perspectives. According to Richards \&Schmidt (2002), the terms learning style, cognitive style and cognitive strategy are used synonymously. They define learning style as the particular way in which a learner tries to learn something. In second or foreign language learning, different learners may prefer different solutions to learning problems.

Wright (1987) asserts that four different learner styles within a group can be identified.

$\sqrt{ }$ The enthusiast looks to the teacher as a point of reference and is concerned with the goals of the learning group.

$\sqrt{ }$ The oracular also focuses on the teacher but is more oriented towards the satisfaction of personal goals.

$\sqrt{ }$ The participator tends to concentrate on group goals and group solidarity

$\sqrt{ }$ The rebel while referring to the learning group for his or her point of reference is mainly concerned with the satisfaction of his or her own goals.

Skehan (1998) believes that the main application of style to language learning has been through the concept of field dependence/independence (FD/I). Cook (2001) believes that the FDs' thinking relates to their surroundings, whereas the FIs think independently of their surroundings.. FI and FD are simply two styles of thinking Griffiths \& Sheen (1992), believe that the concept of FI/FD has not been sufficiently well defined in the research and is no longer of much interest within the discipline of psychology, from which it came. Ehrman and Oxford (1990 as cited in Oxford 2001, p.360) believe that there are nine major style dimensions relevant to L2 learning, but the four dominant styles that are likely to be among those most strongly associated with L2 learning are: sensory preference, personality types, desired degree of generality and biological differences.

In the end to Oxford (2001), learning styles are not dichotomous (black or white, present or absent), but rather generally operate on a continuum or on multiple, intersecting continua. Cohen \& Dornyei, (2002) believe that it is possible that learners over time can be encouraged to engage in ' style-stretching' so as to incorporate approaches to learning they were resisting in the past.

\section{LITERATURE REVIEW}

Reid (1987) conducted a research on different learning styles and cultures and subsequently found that ESL students varied significantly in their sensory preferences with people from certain cultures differentially favoring four different ways of learning. In his research he found that students from Asian cultures, for example, were often highly visual, and in his list Koreans were at the top position. He also found that Hispanic learners were frequently auditory and that Japanese were no auditory. He concluded that ESL students from a variety of cultures were tactile and kinesthetic in their sensory preferences.

According to Hansen (1984) cognitive style varies to some extent from one culture to another. There are variations between learners on different islands in the Pacific and between different genders.(Kachru, 1988; Nelson, 1995) seem to agree with Hansen (1984) and believe that learning styles are both individually and culturally motivating. They assert that within a given culture and on a larger scale, certain learning style preferences among individuals are more pronounced. Oxford, Ehrman \& Lavine, 1991 (as cited in Christison 2003, p.269) believe that this can lead to conflicts in a second language classroom that is made up of students from different language backgrounds when the teacher does not understand the relationship between the students' learning styles and his/her own. We even contemplate that students from different walks of life may have different learning styles preference, in specific different learning sensory style preferences.

Al-Shehri (2009), Yang \& Kim (2011) explored the perceptual learning style, ideal L2 self, and motivated L2 behavior guided by Dörnyei’s $(2005,2009)$ L2 motivational self system, where he characterizes these future imagined self- states as ideal and ought selves in his L2 motivational self-system, where the ideal self represents vision of oneself in the future, while the ought self represents a vision of oneself bearing attributes one feels one should possess.

Al-Shehri (2009) examined the relationship among the learners' visual style, imagination, ideal language selves and motivated behavior. His expectations was that learners with a visual style preference are more likely to access a richer domain of imagination, and that because of the prominent imagery content of the ideal-self, the learners' overall/ imaginative capacity will be positively related to their ideal language selves. Correlational analysis and regression analysis were conducted. The significant correlation confirmed Sheri's hypothesis, indicating that visual learners are more capable of perceiving a vivid representation of their ideal selves, which in turn is reflected in heightened motivated effort and behavior. We think that the same may apply to auditory learners and that perhaps they too could portray an ideal language self. 
Yang \& Kim (2011) explored the perceptual learning style, ideal L2 self, and motivated L2behavior of Chinese, Japanese, South Korean, and Swedish high school students.

The statistical analysis found that learners' perceptual learning styles (i.e., visual, auditory, and kinesthetic styles) were significantly correlated with their ideal L2 self and motivated L2 behavior. The results indicated that although the Chinese students were more likely to show motivated L2 behavior than the other students, they showed a significantly lower level of the ideal L2 self than the Swedish students.

Shakarami \& Mardziha(2010) study indicate that the highest priority for metacognitive strategies for IMES(industrial management engineering students) is in line with a high value for visual and low value for auditory learning style, possibly emphasizing the importance they put on the observation and logical processing and the role of conscious thinking in their ESL learning and decision making in their occupational management task. On the other hand social strategies were reported to be the most frequently used strategies for PSS. (Political science students)

\section{RESEARCH QUESTION}

Based on the issues raised above, to our knowledge, not much research has tried to see the relationship between the sensory style preference of learners and their years of experience as English students in Iran. To this end, the authors have tried to address the following question:

Is there any significant relationship between the sensory style preference of learners and their years of experience as EFL (English Foreign Language) students?

\section{METHOD}

\section{A. Participants}

The participants of this study consisted of 60 junior high school students; studying at a state school in the city of Mashhad. They were all girl students with the average age of fourteen. The participants were divided into two groups: experienced group and inexperienced group. The division was done according to the amount of time they had experienced studying English ranging from zero to four years. Those who had studied English for only a year or below that amount were categorized as the inexperienced group. Those who had studied more than one year were categorized as the experienced group. Consequent to outlining the division, twenty-nine students were categorized as inexperienced and the remaining thirty- one students were categorized as experienced.

\section{B. Instrumentation}

Two questionnaires were used in this study. The first one was a demographic questionnaire which consisted of ten questions regarding personal information, levels of education, names of school, previous English score, experience of learning English and the discourse of learning English (See Appendix). Some of these questions included some sub-questions like experience sections which asked questions regarding types of input they exposed themselves to for learning or enjoying English. The second questionnaire was the learning Channel Preference Checklist which was taken from O'Brian (1990) for the purpose of this study.

This questionnaire identified three types of styles the author named as Visual. Questions 1 (I can remember something better if I write it down), 5 (I am able to visualize pictures in my head), 9 (I take lots of notes on what I read and hear), 10(It helps me to LOOK at a person speaking. It keeps me focused.), 11 (It's hard for me to understand what a person is saying when there is background noise.), 16 (It's easier for me to get work done in a quiet place.), 17 (It's easy for me to understand maps, charts, and graphs), 22 ( When I am concentrating or reading or writing, the radio bothers me), 26 (When taking a test, I can "see" the textbook page and the correct answer on it.), 27 (I cannot remember a joke long enough to tell it later), 32 (When I am trying to remember something new, for example, a telephone number, it helps me to form a picture of it in my head.) and 36(When I get a great idea, I must write it down right away or I'll forget it.)

The second component was named Auditory. Items 2 (When reading, I listen to the words in my head or I read aloud), 3 ( I need to discuss things to understand them better), 12 (I prefer having someone tell me how to do something rather than having to read the directions myself), 13 (I prefer hearing a lecture or tape rather than reading a textbook), 19 (I remember what people say better than what they look like), 20 (I remember things better if I study aloud with someone), 23 (It's hard for me to picture things in my head), 24 (I find it helpful to talk myself through my homework assignments), 28(When learning something new, I prefer to listen to information on it, then read about it, then do it, 29 (I like to complete one task before starting another, and 33 (For extra credit, I prefer to do a report on tape rather than write it.

The third component was Hap tic. The items 4 (I don't like to read or listen to directions; I'd rather just start doing), 6 (I can study better when music is playing), 7 (I need frequent breaks while studying), 8 (I think better when I have the freedom to move around; studying at a desk is not for me), 14 (When I can't think of a specific word, I use my hands a lot and call something a 'what-cha-ma-call-it' or a 'thing-a ma-jig.'), 18 (When beginning an article or book, I prefer to take a peek at the ending.), 21 (I take notes, but never go back and read them, 25 ( My notebook and my desk may look messy, but I know where everything is), 30 (I use my fingers to count and move my lips when I read), 31 (I dislike 
proofreading my book), 34 (I daydream in class), and 35 (For extra credit, I'd rather create a project than write a report.)

\section{Procedure}

The questionnaires were translated into Farsi and were reviewed by two expert Farsi speakers in order to check the clarity of the sentences. Then the teacher who is the current teacher of the participants in this study kindly helped in gathering the information. The participants answered each question along with the teacher in the sense that after the teacher read the question; she gave them 30 seconds to respond to the question. In this way she could solve any probable ambiguities.

\section{Variables}

There are two independent variables in this study. One independent variable includes school (level) which consists of Junior high school. The independent variable is experience or years of learning English outside of high school which has two levels: those who have attended English classroom more than one year and those who have not attended English classroom at all or less than 6 months. These variables are nominal.

Another independent variable which has three levels of Visual, Auditory, and Haptic. These variables are interval.

\section{E. Data Analysis}

To answer the question of this study, several descriptive and inferential data analyses were utilized.

Descriptive Analyses Number One: Percentage and Frequency

To show the distribution of participants over two independent variables different descriptive analyses were run. The independent variables in this study were type of sensory style preference; visual-verbal, visual-nonverbal, and auditory), experience (whether they attended any institution before). The results are shown in Table 1 for the third grade junior high students. As it is shown in this Table, from among 60 participants studying in their third grade junior high school, 31 students stated that they had the experience of going to English institute (51.7\%) and 29 students stated that they had not $(48.3 \%)$. Also, from among this number, 29 students $(48.3 \%)$, and 31 students $(5 \%)$ assessed themselves as being elementary, intermediate and advanced respectively.

TABLE 1:
\begin{tabular}{|l|l|l|l|l|l|}
\hline \multicolumn{9}{|c|}{} \\
\hline & & Frequency & Percent & Valid Percent & Cumulative Percent \\
\hline Valid & EXPERIENCED & 31 & 51.7 & 51.7 & 51.7 \\
\hline & INEXPERIENCED & 29 & 48.3 & 48.3 & 100.0 \\
\hline & Total & 60 & 100.0 & 100.0 & \\
\hline
\end{tabular}

The reliability of the questionnaire was estimated. The result is shown in Table 2.As is shown in this table,Cronbach Alpha for the questionnaire is 0.73 . This is fairly acceptable for a 36 item questionnaire.

TABLE 2:

CHRONBACH AlPHA FOR READING MOTIVATION QUESTIONNAIRE

\begin{tabular}{|l|l|}
\hline Cronbach's Alpha & N of Items \\
\hline .73 & 36 \\
\hline
\end{tabular}

Next, to estimate the validity of the questionnaire, principal component analysis through the varimax rotation method was run. Three components of Visual verbal, Auditory and Visual nonverbal were subjected to SPSS. The result is shown in Table 3.

TABLE 3

FACTOR ANALYSIS WITH VARIMAX ROTATION

\begin{tabular}{|l|l|l|l|l|l|l|}
\hline & \multicolumn{5}{|l|}{ Initial Eigenvalues } & \multicolumn{3}{l|}{ Extraction Sums of Squared Loadings } \\
\hline Component & Total & \% of Variance & Cumulative \% & Total & \% of Variance & Cumulative \% \\
\hline 1 & 1.777 & 44.418 & 44.418 & 1.065 & 26.624 & 26.624 \\
\hline 2 & 0.874 & 21.841 & 66.259 & & & \\
\hline 3 & .699 & 17.482 & 83.741 & & & \\
\hline 4 & .650 & 16.259 & 100.000 & & & \\
\hline
\end{tabular}

Tables $3 \& 4$ show the construct validity of the components of the learning styles. All of the four components of the learning style load on a single factor which shows that they all tap on the same underlying construct. 
TABLE 4

FACTOR ANALYSIS OF QUESTIONNAIRE

\begin{tabular}{|l|l|}
\hline \multirow{2}{*}{} & Components \\
\cline { 2 - 2 } & 1 \\
\hline Visual Verbal & .628 \\
\hline VisTacKin & .522 \\
\hline Auditory & .500 \\
\hline VisualNoverbal & .385 \\
\hline
\end{tabular}

Extraction Method: Principal Component Analysis.

To answer the question of this study "Is there any significant relationship between the sensory style preference of learners and their years of experience as EFL students?" two sets of Pearson correlation coefficients were calculated between the four components of the learning styles (Visual / Verbal, Visual / Non-Verbal, Auditory and Visual / Tactile / Kinesthetic) for experienced and inexperienced students. Tables 5 and 6 are indicative of the results.

TABLE 5

PEARSON CORRELATION COMPONENTS OF LEARNING STYLES FOR EXPERIENCED STUDENTS

\begin{tabular}{|c|c|c|c|c|}
\hline & & $\begin{array}{l}\text { VISUALNON } \\
\text { VERBAL }\end{array}$ & AUDITORY & VISTACKIN \\
\hline \multirow{2}{*}{$\begin{array}{l}\text { VISUALVERB } \\
\text { AL }\end{array}$} & Correlation & .232 & $.533 * *$ & $.423 *$ \\
\hline & Sig. (2-tailed) & .210 & .002 & .018 \\
\hline \multirow{2}{*}{$\begin{array}{l}\text { VISUALNON } \\
\text { VERBAL }\end{array}$} & Correlation & & .212 & .060 \\
\hline & Sig. (2-tailed) & & .251 & .750 \\
\hline \multirow[t]{2}{*}{ AUDITORY } & Correlation & & & $.360 *$ \\
\hline & Sig. (2-tailed) & & & .047 \\
\hline
\end{tabular}

As displayed in Table 5, out of the six correlation coefficients that were calculated, three were significant. There is a significant relationship between visual verbal and auditory learning style (Alphas $=0.53$ ). There is a significant relationship between visual verbal and Visual Tactile Kinesthetic. (Alphas= 0.42); and There is a significant relationship between auditory and Visual Tactile Kinesthetic (Alphas=0.36).

TABLE 6

PEARSON CORRELATION COMPONENTS OF LEARNING STYLES FOR INEXPERIENCED STUDENTS

\begin{tabular}{|l|l|l|l|l|}
\hline \multirow{2}{*}{ VISUALVERBAL } & & VISUALNONVERBAL & AUDITORY & VISTACKIN \\
\hline \multirow{2}{*}{ VISUALNONVERBAL } & Correlation & .350 & .161 & .227 \\
\cline { 2 - 5 } & Sig. (2-tailed) & .063 & .403 & .235 \\
\hline & Correlation & & .108 & .335 \\
\cline { 2 - 5 } & Sig. (2-tailed) & & .577 & .076 \\
\hline & Correlation & & & .247 \\
\cline { 2 - 5 } & Sig. (2-tailed) & & .196 \\
\hline
\end{tabular}

As it is shown in table 6 none of the correlation coefficients for the inexperienced students were significant.

\section{DISCUSSION}

The purpose of this study was to find an answer to the research question: "Is there any significant relationship between the sensory style preference of learners and their years of experience as EFL students?" Two questionnaires were used in this study. The first one was a demographic questionnaire which consisted of ten questions regarding personal information, levels of education, names of school, previous English score, experience of learning English and the discourse of learning English. The second questionnaire was the learning Channel Preference Checklist which was taken from O'Brian (1990) for the purpose of this study.

To answer the question of this study, several descriptive and inferential data analyses were utilized. The results showed that out of the six correlation coefficients that were calculated, three were significant, which suggests that there is a correlation between the sensory style preferences of experienced students, hence the experienced students are more flexible in their preference. As mentioned in the literature to Oxford (2001), learning styles are not dichotomous (black or white, present or absent), but rather generally operate on a continuum or on multiple, intersecting continua and the results for the experienced students are indicative of this fact. Perhaps the amount of time that these students have put in studying English have made them more fluid learners who can adapt their styles to best meet their needs. However, the same concept cannot be felt for the inexperienced students. Cohen \& Dornyei, (2002) believe that it is possible that learners over time can be encouraged to engage in ' style-stretching' so as to incorporate approaches to learning they were resisting in the past. Consequently it is up to the teacher to try to provide opportunities for students' sensory style development. 


\section{CONCLUSION}

As the goal of any teacher is to better meet the individual needs of their students, then it seems that the only way would be to address the diversity that is felt in the classroom, and better prepare students for their classroom language learning experiences by working with learning styles and applying concepts regarding learning styles available. The teacher is in an ideal position to aid students become more comfortable with learning approaches they have not previously experienced. Students need to know that their individual needs will not be accommodated at all times, and that even sensitive teachers must make informed decisions about which instructional approach will most efficiently transmit the material to be covered. One of the apparent implications of this study is that experienced learners are more flexible regarding their learning styles. Teachers, especially at elementary level have to be more sensitive to the learning styles of the students. Teachers at higher levels are freer in their approach to learning styles. Leading students to a more critical awareness of their individual learning strengths and challenges results in empowering them to fully realize their potential in academic settings and need to assume more learner responsibility. Teachers may use a variety of activities to provide structured opportunities for students to explore their individual learning styles.

\section{APPENDIX A}

Read each sentence carefully and think how it applies to you. On each line, write the number that best describes your reaction to each sentence.

5. -----Almost Always 4. -----Often 3. -----Sometimes $\quad$ 2. ----- Rarely 1. ----- Almost Never

------1. I can remember something better if I write it down.

-2 .When reading, I listen to the words in my head or I read aloud.

-3. I need to discuss things to understand them better.

4.I don't like to read or listen to directions; I'd rather just start doing.

-5 . I am able to visualize pictures in my head.

-6. I can study better when music is playing.

-7. I need frequent breaks while studying.

-8. I think better when I have the freedom to move around; studying at a desk is not for me.

-9. I take lots of notes on what I read and hear.

-10. It helps me to LOOK at a person speaking. It keeps me focused.

-11. It's hard for me to understand what a person is saying when there is background noise.

-12. I prefer having someone tell me how to do something rather than having to read the directions myself.

13. I prefer hearing a lecture or tape rather than reading a textbook.

-14.When I can't think of a specific word, I use my hands a lot and call something a 'what-cha-ma-call-it' or a

'thing-a ma-jig.'

-15.I can easily follow a speaker even though my head is down or I'm staring out the window.

-16. It's easier for me to get work done in a quiet place.

------17. It's easy for me to understand maps, charts, and graphs.

-18. When beginning an article or book, I prefer to take a peek at the ending.)

-19. I remember what people say better than what they look like.

20.I remember things better if I study aloud with someone.

21.I take notes, but never go back and read them.

-22 . When I am concentrating or reading or writing, the radio bothers me.

-23 . It's hard for me to picture things in my head.

-24. I find it helpful to talk myself through my homework assignments.

-25 . My notebook and my desk may look messy, but I know where everything is.

-26 . When taking a test, I can "see" the textbook page and the correct answer on it.

-27. I cannot remember a joke long enough to tell it later.

-28. When learning something new, I prefer to listen to information on it, then read about it, then do it.

-29. I like to complete one task before starting another.

-30 . I use my fingers to count and move my lips when I read.

-31. I dislike proofreading my book.

-32. When I am trying to remember something new, for example, a telephone number, it helps me to form a picture of it in my head.

-33 . For extra credit, I prefer to do a report on tape rather than write it.

-34. I daydream in class.

-35.For extra credit, I'd rather create a project than write a report.

-36 . When I get a great idea, I must write it down right away or I'll forget it.

APPENDIX B 


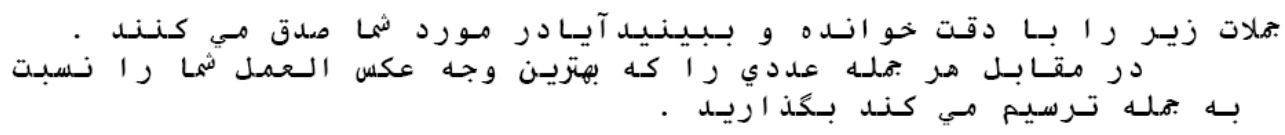

1. هميشه 2. اكثر مواقع

\begin{tabular}{|c|c|c|c|c|c|}
\hline 5 & 4 & 3 & 2 & 1 & 1) اكر جِيزي را بنويسنيم بهتر به خاطر مي سبارم . \\
\hline 5 & 4 & 3 & 2 & 1 & 2) در هنكام آر ام خو اندن ، در ذهنم به تلك تلك كلمات كوش مي د هم و بيا به صورت بلند مي خو انم \\
\hline 5 & 4 & 3 & 2 & 1 & 3) بر اي ابنكه مطلبي ر ا خوب متوجه شوم بهتر آن است كه مر مورد آن با افر اد مطلع كفتكو كنم . \\
\hline 5 & 4 & 3 & 2 & 1 & 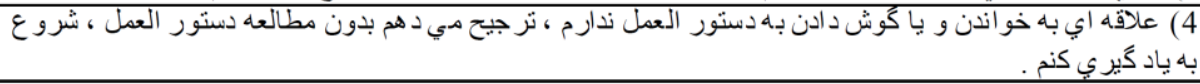 \\
\hline 5 & 4 & 3 & 2 & 1 & 5) من ميتو انم عكسها را در ذهنم تجسم كنم. . \\
\hline 5 & 4 & 3 & 2 & 1 & 6) من با موزيك بهتر برس مي خو انم. . \\
\hline 5 & 4 & 3 & 2 & 1 & 7) در هنغام مطالعه ، من احتباج به زمان استر احت مكرر دارم . \\
\hline 5 & 4 & 3 & 2 & 1 & 8) مطالعه بُشت مبز براب من مناسب نيست ، اكر آز ادي حركت داشُته باشُ ، بهتر ياد مي كَير م . \\
\hline 5 & 4 & 3 & 2 & 1 & 9) در مورد مطالبي كه مي خو انم و با كوش مي كنم ، بادداشتهابي فر او اني مي نوبيسم . \\
\hline 5 & 4 & 3 & 2 & 1 & 10) و قتتي كسي صدبت مي كند ، نكاه كردن به آن شخص به من كمك مي كند تار رو موضو ع متمركز شوم \\
\hline 5 & 4 & 3 & 2 & 1 & 11) اكز سر و صدا باشد ، براب من سخت است كه صدحبنهاب طرف مقابل را منوجه شوم . . \\
\hline 5 & 4 & 3 & 2 & 1 & 12) بر ابي انجام كاري ترجيج مي دهم شخصي دستور العمل را بر ايم توضبيح ده تنا ابنكه خودم آنر ا بخو انم \\
\hline 5 & 4 & 3 & 2 & 1 & 13) ترجيجح مي دهم به سخنر اني و بـا مطلبي كُوش دهم تا ابنكه متني را بخو انم . \\
\hline 5 & 4 & 3 & 2 & 1 & 14) وقتي لغت خاصي را بباد نمي آورم ، خيلي از دستهابم استفاده مي كنم و از لغت " جيز " استفاده مي كنم \\
\hline 5 & 4 & 3 & 2 & 1 & 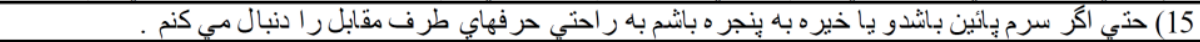 \\
\hline 5 & 4 & 3 & 2 & 1 & 16) اكر در محبط آر ام كار هايم انجام شو ند ، برايم راحتزر است . . \\
\hline 5 & 4 & 3 & 2 & 1 & 17) نقشه ، جارت و كر اف بر ابم به ر احتي قابل درك هيتند . \\
\hline 5 & 4 & 3 & 2 & 1 & 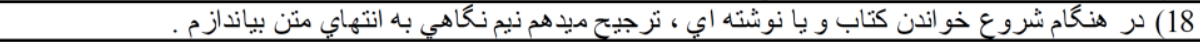 \\
\hline 5 & 4 & 3 & 2 & 1 & 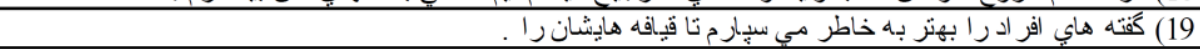 \\
\hline 5 & 4 & 3 & 2 & 1 & 20) اكر همر اه شخصي با صداب بلند مطالعه كنم ، مطالب را بهنز به خاطر مي سيارم . \\
\hline 5 & 4 & 3 & 2 & 1 & 21) بادداشت زباد بر مي دارم ولي هبج وقت آنهار را مطالعه نمي كنم . . \\
\hline 5 & 4 & 3 & 2 & 1 & 22) وقتي در خو اندن و نوشُنْ دقت مي كنم حتي صدابي ر ادبو مر ا اذيت نمي كند \\
\hline 5 & 4 & 3 & 2 & 1 & 23) تُجم كردن بر ابم سخت است . . \\
\hline 5 & 4 & 3 & 2 & 1 & 24) در انجام تكاليف خانه با خود صحبت كردن به من كمك مي كند . . \\
\hline 5 & 4 & 3 & 2 & 1 & 25) هر جند دفتز بادداشت و يا ميز مطالعه ام نا مرتب به نظر برسند ، ولي من جاب هر جيز را مي دانم . \\
\hline 5 & 4 & 3 & 2 & 1 & 26) در هنكًام امتحان دادن ، من مبنو انم صفحه كتابي كه جو اب درست در آن است و من قبلا" آنر ا مطالعه كردمبه \\
\hline 5 & 4 & 3 & 2 & 1 & 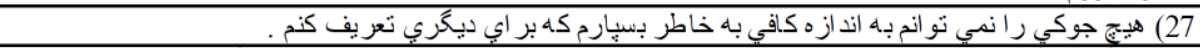 \\
\hline 5 & 4 & 3 & 2 & 1 & 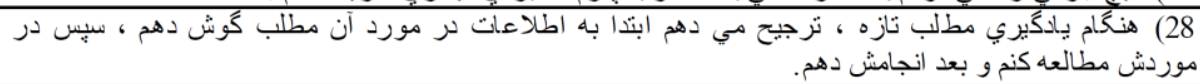 \\
\hline 5 & 4 & 3 & 2 & 1 & 29) ترجيح مي دهم كاري را به اتمام برسانم و بعد كار جديد را شروع كنم. . \\
\hline 5 & 4 & 3 & 2 & 1 & 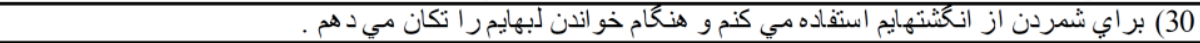 \\
\hline 5 & 4 & 3 & 2 & 1 & 31) از بازنكگري نوشته هايم خوشم نمي أبد. . . \\
\hline 5 & 4 & 3 & 2 & 1 & مبكند. هنكامي كه مي خو اهم مطلب جديدي ر ا به خاطر بياورم ، مثّلا" شماره ذّلفن ، تجسم اعداد در ذهنم به من كمك \\
\hline 5 & 4 & 3 & 2 & 1 & 33) بر اب دريافت يوئن مثبت تر جيح مي دهم ، يك كز ارشي روب نو ار تهيه كنم تنا اينكه كز ارش را بنويسم \\
\hline 5 & 4 & 3 & 2 & 1 & 34) سر كلاس درس رو با بِردازي مي كنم. . \\
\hline 5 & 4 & 3 & 2 & 1 & 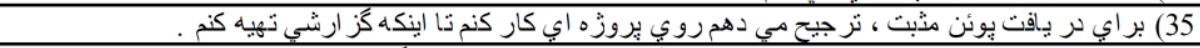 \\
\hline 5 & 4 & 3 & 2 & 1 & 36) و قتتي بك ابده عالي به ذ هنم مي رسد بايد فور ا" آنر ا روب كاغذ بياور م و كرنه فر اموشُش مي كنم \\
\hline
\end{tabular}

\section{REFERENCES}

[1] Al-Shehri, A. S. (2009). Motivation and vision: The relationship between the ideal L2 self, imagination and visual style. In E. Ushioda\& Z. Dornyei (Eds.), Motivation, language identities and the L2self (pp.164-172). Bristol: Multilingual Matters.

[2] Anderson, N.J. (2005). L2 strategy research. In E. Hinkel (Ed.), Handbook in second language teaching and learning. (pp.757-775). Mahwah, NJ: Erlbaum.

[3] Celce-Murcia, M. (2001).Language teaching approaches: an overview .In M. Celci-Murci (Ed.), Teaching English as a Second or Foreign Language. (pp.3-27).Boston: Heinle \&Heinle.

[4] Christison, M. A. (2003). Learning styles and strategies. In D. Nunan (Ed.), Practical English language teaching. New York: McGraw Hill.

[5] Cohen, A. D., \& Dornyei, Z. (2002).Focus on language learner: motivation, styles and strategies. In N. Schmitt (Ed.), An introduction to applied linguistics. (pp.170-190). London: Arnold.

[6] Cohen, A.D., \& Macaro, E. (2007). (Eds.), Language learner Strategies. Oxford: Oxford University Press.

[7] Cook, V. (2001). Second language learning and language teaching. (3rd.ed.) . London: Arnold.

[8] Dorneyi, Z. (2005). The Psychology of the language learner: Individual differences in second language acquisition. Mahwah, 
NJ: Lawrence Erlbaum Associates.

[9] Dörnyei, Z. (2009). The L2 motivational self system. In Z. Dörnyei \& E. Ushioda (Eds.), Motivation, language identity and the L2 Self (pp. 9-42). Bristol, UK: Multilingual Matters.

[10] Griffiths, R. \& Sheen, R. (1992).Disembedded figures in the landscape: a reappraisal of L2 Research on field dependence/ independence. Applied Linguistics 13(2), 133-147.

[11] Hansen, L. (1984). Field dependence-independence and language testing: evidence from six Pacific Island cultures. TESOL Quarterly 18(2), 311-324.

[12] Harmer, J. (2001).The practice of English language teaching.( 3rd.ed.). Cambridge: Longman.

[13] Haynes, J. (2008). Teach to students' learning styles. Retrieved March, 2, 2011, from http://www.everythings1.net/inservices/learningstyle.php

[14] Kachru, Y. (1988). Cognitive and cultural styles in second language acquisition. Annual Review of Applied Linguistics, 9 (2), 149-163.

[15] Kinsella, K. (1995). In J. M. Reid (Ed.) Learning styles in the ESL/EFL classroom.(pp170-196) .Boston, MA: Heinle \& Heinle.

[16] Nelson, G. (1995). Understanding and empowering diverse learners. In J. M. Reid (Ed.) Learning styles in the ESL/EFL classroom. (pp.3-20) .Boston, MA: Heinle \& Heinle.

[17] Oxford, R.L. (2001). Language learning styles and strategies. In M. Celci-Murcia (Ed.)Teaching English as a Second or Foreign Language.(pp.359-366). Boston: Heinle \& Heinle.

[18] Reid, J. (1987). The learning style preferences of ESL students. TESOL Quarterly 21(1), 87-111.

[19] Reid, J.M. (Ed.). (1995). Learning styles in the ESL/EFL classroom. Boston, MA: Heinle \& Heinle.

[20] Richards, J. C., \& Rodgers, Th. S. (2001).Approaches and methods in language teaching (2nded.). Cambridge: CUP.

[21] Richards, J.C. \& Schmidt, R. (2002).Dictionary of language teaching and applied linguistics. (3rd.ed.) .Essex: Longman.

[22] Shakarami, A. \& Mardziha, H. A. (2010).Language learning strategies and styles among Iranian engineering and political science graduate students studying abroad. Educational Research and Reviews 5(2), 35-45.

[23] Skehan, P. (1998). A cognitive approach to language learning. Oxford: Oxford University Press.

[24] Wright, T. (1987). Roles of teachers and learners. Oxford: Oxford University Press.

[25] Yang, J\& Kim, T (2011). The L2 Motivational Self System and Perceptual Learning Styles of Chinese, Japanese, Korean, and Swedish Students. English Teaching, 66(1), xxx-xxx

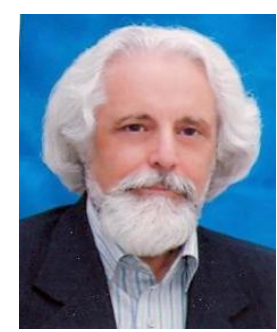

Mansoor Fahim was born in Nahavand in 1946. He received a Ph.D. in TEFL from Islamic Azad University in Tehran, Iran in 1993.

As for his professional background, he was a member of the faculty of English Language and Literature at Allameh Tabataba'i University in Tehran, Iran from 1981 to 2008 when he was retired as an associate professor of TEFL. He has taught English at a welter of universities. At present, he runs Research methods, Psycholinguistics, Applied Linguistics, Second Language Acquisition, and Seminar classes at M.A. level and First Language Acquisition, Psycholinguistics, and Discourse Analysis courses at Ph.D. level at a number of universities including Allameh Tabataba'i and Islamic Azad Universities. Moreover, he has several published articles and books mostly in the field of TEFL and has translated some books into Farsi.

Dr. Fahim is currently a member of the editorial board of some Iranian journals of Applied Linguistic Studies.

Tania Samadian was born in Tehran in 1977. She received an M.A. in TEFL from the University of Tehran in 2008.She is currently a Ph.D. student of TEFL at the Islamic Azad University in Tehran, Iran. As for her professional background, she has taught the English course at various universities e.g. The International University of Chabahar, The International Branch of Polytechnique University in Tehran, and currently Allameh Tabataba'i University and Islamic Azad University in Tehran. Moreover, she has translated many papers into Farsi. 